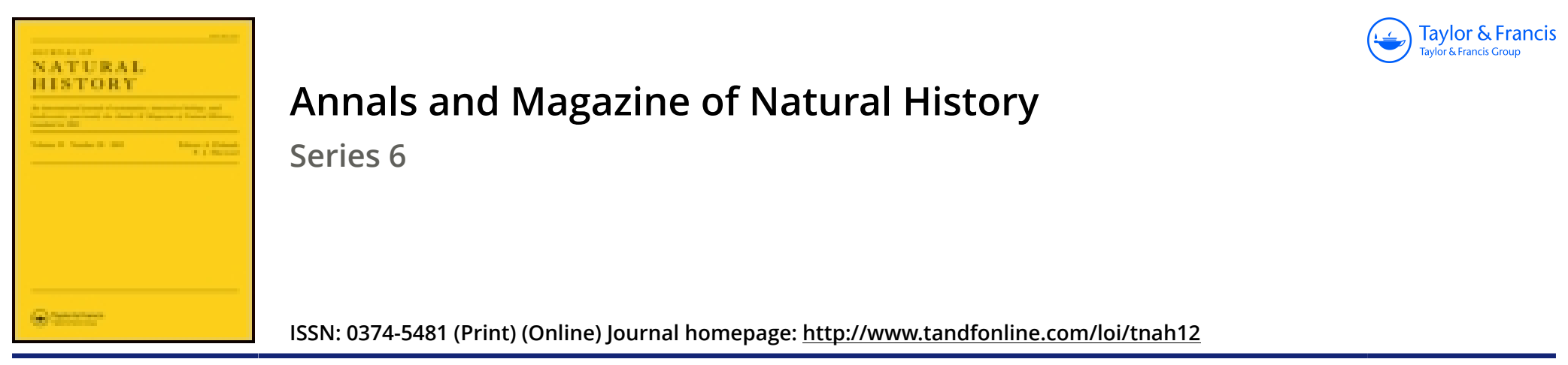

\title{
On the status of the names Aplysia and Tethys
}

\section{Henry A. Pilsbry}

To cite this article: Henry A. Pilsbry (1895) On the status of the names Aplysia and Tethys, Annals and Magazine of Natural History, 16:95, 424-427, DOI: 10.1080/00222939508680297

To link to this article: http://dx.doi.org/10.1080/00222939508680297

$$
\text { 曲 Published online: } 06 \text { Oct } 2009 .
$$

Submit your article to this journal $2 \pi$

Џll Article views: 4

Q View related articles $\asymp$ 
length; pleuro densely porous, terminating in a blunt process, which is tipped with 4 or 5 small spines; sternite long and narrow, posteriorly attenuate, with truncate hinder edge, its basal width about two thirds of its length ; legs long and slender, nearly four times the length of the head, the segments cylindrical and about four times as long as wide; femora armed with about 14 small spines, 3, 3, 2 in three longitudinal rows on the inner surface and 3,3 in two rows on the external half of the lower surface; the femoral process armed with from 4 to 10 small spines; no tarsal spur, claws basally spurred.

The rest of the legs long and slender, with a tarsal spur.

Measurements in millimetres. - Total length 163 , of antenna 37, of anal leg 41 ; width of head 10.5 , length 10 ; width of twelfth tergite 14 , of twenty-first 8 .

Loc. New Georgia (Solomon Islands).

A couple of specimens of this species were obtained by Commander Barker, R.N., of H.M.S. 'Penguin.' The second specimen is a little smaller than the type, being 145 millim. long, and much more uniformly chestnut in colour.

In its general features this handsome new species presents considerable resemblance to the cosmopolitan S. subspinipes of Leach, but may be at once recognized by the spine-armature of its anal legs, the former species having only two or three spines on tho lower surface of the anal femora and only three or four on the inner surface. It also has but five or six teeth on the precoxal plates of the maxillipedes, whereas in $S$. metuendr there are a large number of minute more or less obsolete teeth on these plates. In this respect S. metuenda would seem to approach S. polyodonta, Daday (Term. füzetek, xvi. p. 109 , pl. v. fig. $7 \&$ \&), from New Guinea; but the latter has the anal femora unarmed, as in the variety of $S$. de Haanii named inermis by Newport.

MISCELLANEOUS.

On the Status of the Names Aplysia and Tethys. By Henry A. Pilsbry.

Is the course of my studies on the "Sea-Hares," preliminary to the preparation of a monograph of this group of tectibranch mollusks for the 'Manual of Conchology,' my attention was early forced to the fact that in Linneus's tenth edition of the 'Systema Naturæ' the genus Tethys was proposed for the animal now known as Aplysia, and included nothing else. Moreover, by the terms of the generic diagnosis, such creatures as that known as Tethys in modern times are excluded.

In the twelfth edition of the 'Systema' Tethys is given a completely different meaning, and the new term Aplysia (Laplysia) is brought forward to include the species of the earlier Tethys. This later usage has been accepted by zoologists until the present day. 
The question then arises, Shall we apply to Linnæus himself the canons of nomenclature which would be rigorously enforced were the claims of his successors in question? It is with a view to obtaining the opinions of those who are expert in these matters that we present below a full synopsis of the literature bearing upon the questions at issue.

The facts in this case have doubtless been fully unearthed by many investigators; but, probably believing it best to "let sleeping dogs rest," no one* has to my knowledge seriously raised the questions to which I desire now to direct attention.

The genus T'thys was founded by linné in the tenth edition of the 'Systema Naturx,' p. 653, for two species, thus :-

"254. Tетнтs. Corpus oblongum, bilabiarum : corpusculo medio cartilagineo oblongo. Tentacula duo, cuneiforma. Foramina duo, spirantia.

"limacina 1. T. auriculis quatuor.

"Habitat in Oceano Australi.

"Corpus oblongum, antice quasi 4 auriculis acutis instructum. “leporina. 2. T. corpore rubro, margine membranaceo, auriculis duobus.

"[a] Rond. pisc. 1. p. 520. Lepus marinus.

"[b] Bell. aquat. 437 . Lepus marinus.

"[c] Gesn. aquat. 475. Lepus marinus. Aldr. exsangu. 78. Lepus marinus 1 .

"Habitat in M. Mediterraneo.

"Conf. Column. aqu. t. 26, f. 2, 3."

It will be noticed that the above description of limacina contains nothing diagnostic of a species, though the genus is clearly indicated. As Linné gives us no reference to earlier writers, we have absolutely no means of learning what Tethys limacina is, and the name must be dropped.

In the case of leporina, Linné gives ample references to the sources whence his information was derived. These we analyze as follows:[a] Gulielmi Rondeletii, etc., Libri de Piscibus Marinis, etc. (1554), Liber xvii. p. 520, figures an Aplysia which seems to be the A. fasciata of authors (for it lacks the conspicuous shell-foramen of depilans and the broadly united parapodia of punctata). [b] $\mathrm{La}$ Nature \& diversité des poissons, avee leurs pourtraicts, representez au plus pres du naturel, par Pierre Belon du Mans (Paris, 1555), p. 437 , seems to be an undeterminable species of "Lievre Marin" from the Cyclades, known to Belon through the ancient authors only. [c] Conradi Gesneri medici Tigurini Historiæ Animalium, Liber IIII. qui est de Piscium \& Aquatilium Animantium natura (1558), p. 561 (Linné wrongly gives 475 as the page). A reversed copy of Rondelet's figure is given, Gesner's information being wholly second hand. [d] Ulyssis Aldrovandi etc., De Reliquis Animalibus

* Except R. Bergh, who in Mal. Unters. i. p. 33, in Semper's ' Reisen,' 2ter Theil, has made the bald statement that Linnæus's earlier Tethys was an Aplysia, but who continues to use Tethys for the Nudibranch.

Ann. \& Mag. N. Hist, Ser. 6. Vol. xvi. 
exanguibus, libri quatuor, post mortem eius editi Nempe De Mollibus, Crustaceis Testaceis, et Zoophytis (1606), De Mollibus, liber I. p. 78. In this work, which is purely a compilation, all of Rondelet's figures again do service, and Linnæus's reference will naturally be confined to the first of these. Aldrovandus also figures (p. 82) a couple of species of Doris as "Leporis marini alia species," and (p. 83) two other figures possibly representing Aclesia. Linné's "conf. Columna" refers us to figures of the Nudibranch commonly known as Tethys fimbria ; but this figure is merely cited for comparison, not as a representation of the species $T$. leporina.

It would therefore seem that Linné originally intended Tethys for the Aplysia species, his generic diagnosis and references unmistakably indicating the "Lepus marinus" of the early zoological renaissance authors.

In the twelfth edition of the 'Systema,' p. 1089, Linné wholly alters the diagnosis of Tethys, as follows :-

“289. Tetris. Corpus liberum, oblongiusculum, carnosum, apodum. Os proboscide terminale, cylindrica, sub labis explicato. Foramina 2 ad latis colli sinistrum.

"leporin. 1. T. labro ciliato. $\dagger$

"Column. aquat. 27. †. 26. Lepus marinus major.

"Rondel. pisc. 526. Leporis marini tertia species.

"Habitat in Mari Mediterraneo.

"fimbria. 2. T. labro crenulato.

"Bohads. mar. 54 t. 5.f. 1, 2. Fimbria.

"Habitat in mari adritico.

"Videtur a proecedenti distincti species."

All of these references belong to the one Mediterranean species (see Bergh, in Semper's ' Reisen,' 2ter Theil, ii. p. 348), known as Tethys fimbria or leporina*.

On page 1082 of the twelfth edition the new genus Aplysia or Laplysia $\ddagger$ is proposed, thus:-

* The specific name of this Nudibranch must stand fimbria, Linn., the binomial combination Tethys leporina being preoccupied by Linnæus, 1758. The synonymy of the genus is as follows:-

1761. Fimbria, Bohadsch, 1761 (a mononym).

1767. Tethys, L. 1767, not Tethys, L. 1758.

1801. Tethis, Lam. Syst. An. s. Vert. p. 63.

1808. Thethys, Cuvier, Ann. du Mus. d'Hist. Nat. xii. p. 257.

1808. Thetis, Meckel, Beytr. zu vergleich. Anat. I. i. p. 9, not Thetis, J. Sowb. Min. Conch. 1826.

1817 ?. Thetys, Fér. Tabl. Syst. p. 28.

1819. Phoenicurus, Rudolphi, Entozoorum Synopsis, p. 573.

1823. Vertumnus, Otto, Nov. A. Ac. C. Leop. Nat. Cur. xi. pp. 294300 .

Of these names, the first was not distinctly proposed as a genus, Bohadsch's nomenclature being strictly mononymic. The seventh and eighth were founded on minute appendages of the animal, supposed to be parasitic worms; and certainly the genus could not be identified by these descriptions. The other names are variants on Linnæus's original Tethys. † The spelling "Laplysia" is evidently a typographical error or over- 
“ 283. Laplysia. Corpus repens, obvelatum membranis reflexis.

"Clypeo dorsali, membranaceo, pulmones obtegente.

"Forcemen laterale, dextrum, pro genitalibus.

"Anus supra extremitatem dorsi.

"Tentacula quatuor, anterius sita.

"depilans. 1. Laplysia.

"Syst. Nat. 10. p. 653. Tethys limacina.

"Rond. pise. 1. p. 520. Lepus marinus.

"Gesn. aquat. 475. Lepus marinus Rondeletii.

"Bohads. mar. 3. t. 1, 2, 3. Lernea graphice.

"Seb. mus. 3. t. 1, f. 8, 9 .

"Habitat in M. Mediterraneo; sanie depilans tactu.

"(B. 51.) foetidissima ad nauseam usque."

The description of the genus is implied for the species depilans, and it is also said to be the Tethys limacina of the tenth edition* The second reference is to the same figure of Rondelet formerly cited for Tethys leporina. The third reference repeats the earlier eitation to Gesner, with the same mistake as to the page. The fourth reference is to the excellent figure of Bohadsch's Lernea, representing unmistakably the Aplysic depilans of authors. The reference to Seba is less happy, the figures being too ambiguous for certain determination. It is perfectly evident that Iinnæus's generic characters of Laplysia were derived from Bohadsch's work; and as the best figures were from the same source, the traditional identification of depilans is fully sustained.

SUMmary.-From the foregoing facts it would appear that (1) the generic name Tethys, Linn. 1758, must replace Aplysia and Laplysia, Linn. 1767; and (2) as a substitute for Tethys, Linn. 1767, not 1758 , we will probably be compelled to adopt either one of the new spellings of this name proposed in the early part of the century or an entirely new generic term.-Proc. Acad. Nat. Sci. Philad. August 27, 1895, pp. 347-350.

On the Origin of the Triradiate Spicules of Leucosolenia. By E. A. Mrnchin.

In Leucosolenia coriacea the youngest spicules are found to be surrounded by six cells, which are similar in all their characters to the cells of the external flat epithelium of the sponge, and undoubtedly derived from this layer. It appears that three cells of the external epithelium wander inwards, and give rise to six by division of each cell into two, the six cells being arranged in such a way that three are placed more internally, i. e. towards the gastral

sight, for the first use of the word, on page 1072 of the Syst. Nat. 12, is in the correct form "Aplysia." The generic diagnosis given on this page is brief, but sufficient :- "283. Aplysia Tentacula 4. Anus supra postica."

* We would not replace the specific name depilans by limacina, because the latter was not recognizably defined in Linnæus's earlier edition. 